NBER WORKING PAPER SERIES

\title{
POLLUTION HAVENS AND FOREIGN DIRECT INVESTMENT: DIRTY SECRET OR POPULAR MYTH?
}

\author{
Beata K. Smarzynska \\ Shang-Jin Wei \\ Working Paper 8465 \\ http://www.nber.org/papers/w8465
NATIONAL BUREAU OF ECONOMIC RESEARCH
1050 Massachusetts Avenue
Cambridge, MA 02138
September 2001

We wish to thank Hans Peter Lankes and Susan Bartolo for kindly providing some of the data and Rachel Rubinfeld and $\mathrm{Yi} \mathrm{Wu}$ for superb research assistance. The views expressed in the paper are those of the authors and should not be attributed to the World Bank or any other organization the authors are affiliated with. The views expressed herein are those of the authors and not necessarily those of the National Bureau of Economic Research.

(C) 2001 by Beata K. Smarzynska and Shang-Jin Wei. All rights reserved. Short sections of text, not to exceed two paragraphs, may be quoted without explicit permission provided that full credit, including $(\mathbb{C}$ notice, is given to the source. 
Pollution Havens and Foreign Direct Investment:

Dirty Secret or Popular Myth?

Beata K. Smarzynska and Shang-Jin Wei

NBER Working Paper No. 8465

September 2001

JEL No. F2

\begin{abstract}
$\underline{\text { ABSTRACT }}$
The "pollution haven" hypothesis refers to the possibility that multinational firms, particularly those engaged in highly polluting activities, relocate to countries with weaker environmental standards. Despite the plausibility and popularity of this hypothesis, the existing literature has found little evidence to support it. This paper identifies four areas of difficulties that may have impeded the researcher's ability to uncover this "dirty secret." This includes the possibility that some features of FDI host countries, such as bureaucratic corruption, may deter inward FDI, but are positively correlated with laxity of environmental standard. Omitting this information in statistical analyses may give rise to misleading results. Another potential problem is that country- or industry-level data, typically used in the literature, may have masked the effect at the firm level. In addition, environmental standard of the host countries and pollution intensity of the multinational firms are not easy to measure. This study addresses these problems present in the earlier literature by taking explicitly into account corruption level in host countries and using a firm-level data set on investment projects in 24 transition economies. With these improvements, we find some support for the "pollution haven" hypothesis, but the overall evidence is relatively weak and does not survive numerous robustness checks.
\end{abstract}

Beata K. Smarzynska

The World Bank

Development Economics Research Group

1818 H St., NW

MSN MC3-303

Washington, DC 20433

Tel: 202-458-8485

Email: bsmarzynska@,worldbank.org
Shang-Jin Wei

The Brookings Institution

Room 731

1775 Massachusetts Avenue

Washington, DC 20036

and Harvard University Center for

International Development

and NBER

Tel: 202-797-6023

Email: $\underline{\text { Swei@brook.edu }}$ 


\section{INTRODUCTION}

The possibility that pollution-intensive multinational firms relocate to developing countries with less stringent environmental standards has been labeled as "pollution haven" or "race-to-thebottom" hypothesis. The logic sounds plausible: if it costs money to conform to more stringent environmental requirements in developed countries, profit-maximizing firms would want to relocate their production activities. The believers abound. For example, the Sierra Club states that that "in our global economy, corporations move operations freely around the world, escaping tough pollution control laws, labor standards, and even the taxes that pay for social and environmental needs."

The only trouble is to find convincing and supportive evidence. The empirical literature on this subject has largely failed to detect a significant correlation between the location decision of multinational firms and the environmental standards of host countries. This includes virtually all the papers surveyed in Dean (1992) and Zarsky (1999). To the best of our knowledge, the only exception is a study by Xing and Kolstad (1998) which reports a positive association between the amount of sulfur emissions in a host country and inflows of U.S. FDI in heavily polluting industries. This evidence is based on a fairly small sample (no more than 22 observations in each regression), so its robustness is subject to debate. In any case, recent papers by Eskeland and Harrison (1997), Letchumanan and Kodama (2000) and Wheeler (2000) again argue that the data does not support the "pollution haven" hypothesis².

There are two possible ways to summarize the existing empirical studies. The first possibility is that the "pollution haven" hypothesis is after all just a popular myth that does not hold in reality. An alternative view is that the "pollution haven" hypothesis is valid but the empirical researchers have not tried hard enough to uncover this "dirty secret."

There are indeed several areas in which researchers face data difficulties that may have impeded their ability to expose the "dirty secret." First, there may be features of developing countries that deter FDI but at the same time are correlated with laxity of environmental protection. A leading example of such a feature is a host country's weakness in public institutions, particularly

\footnotetext{
${ }^{1}$ See "A Fair Trade Bill of Rights" at the Sierra Club website (http://www.sierraclub.org/trade/ftaa/rights.asp)

${ }^{2}$ Different regions in the United States also have different environmental standards. The empirical results on U.S. regional data are mixed. Levinson (1996) finds no evidence that this difference has systematically affected the location choices of manufacturing plants. Becker and Henderson (2000) show, however, that the annual designation of air quality attainment status which triggers specific equipment requirements at the county level in the U.S. reduces the number of firm establishments in polluting industries in nonattainment areas.
} 
the prevalence of bureaucratic corruption. Host country A may have less stringent environmental protection than country $\mathrm{B}$, which might make country A more attractive than country B to foreign direct investment, particularly from the "dirty" industries. On the other hand, country A may also have a more severe corruption problem, which tends to discourage inward foreign investment, including those from the "dirty" industries. Indeed, it seems reasonable to expect corruption and laxity of environmental protection to go together, ${ }^{3}$ so that statistical analysis on the effect of environmental policy on FDI that omits local corruption might fail to detect an effect. Several studies have demonstrated that corruption in a host country is a significant deterrent to inward FDI (Hines, 1995; Wei, 1997, 2000a and 2000b; and Smarzynska and Wei, 2000). This points to the importance of controlling for the effect of corruption in examining the location choices of multinationals.

Second, as Zarsky (1999, p. 66) stated after surveying the empirical literature, "the quality of the evidence, both statistical and case study, is poor compared to the research needs. In terms of location decisions, most of the statistical studies rely on very aggregated data about 'industry choices' which shed little light on firms or production stages." This suggests the usefulness of employing a firm-level data set.

Third, it is very hard to measure the varying strength of environmental protection in different host countries. This difficulty is further exacerbated by the possibility that laws on the book may not be the laws that are actually enforced.

Fourth, assigning pollution intensity measures to production activities of different multinational firms is a very challenging task.

A combination of these difficulties may have prevented researchers from detecting a statistically significant effect of environmental protection on the location choice of multinational firms even if the "pollution haven" hypothesis is valid.

The objective of this paper is to tackle the problems in each of these four areas. First, we will explicitly take into account corruption in a host country as a possible deterrent to FDI (and hence as a compounding factor in the effect of environmental standards on FDI). Second, instead of using country- or industry-level figures, we will make use of a unique firm-level data set that describes the investment decision by 534 major multinational firms in 24 countries in

\footnotetext{
${ }^{3}$ See Damania et al. (2000) for a theoretical and empirical support for this claim.
} 
Central/Eastern Europe and the former Soviet Republics. This represents potentially 12,816 $(=534 \mathrm{X} 24)$ investment decisions at the firm level. ${ }^{4}$

Third, to capture the strength of environmental protection in host countries, we adopt several different measures that complement one another. Specifically, we employ three types of measures: (i) a degree of participation (ratification, signature but no ratification, or neither) in four different international environmental protection treaties, covering transboundary aspects of air pollution, industrial accidents, use of water-courses and lakes, etc. (ii) an index of the strength of the air and water ambient and emission standards system as rated by European Bank for Reconstruction and Development (1997); (iii) the actual reduction in emissions of carbon dioxide, lead and water pollutants (scaled by the GDP growth). Reductions in emissions may be viewed as proxies for a host country's effective enforcement of environmental policies. For the first two measures, effectiveness of enforcement is adjusted by using information on the number of environmental NGOs in a country relative to its population size.

Note that the set of transition economies in the sample includes countries with relatively high income and relatively high environmental standards (in terms of conformity with the European Union standard) such as Poland and Czech Republic. It also covers countries that are substantially poorer and are perceived to have much weaker environmental standards such as Azerbaijan and Uzbekistan. Therefore, there is a reasonably big variation in the host-country environmental standard in our sample.

Fourth, we compute pollution intensity at the four-digit SIC industry level for all multinational firms in our sample, based on the data on actual pollution emissions and abatement cost of U.S. firms filed with the U.S. Environmental Protection Agency (EPA). We have the emissions data for 269 and the abatement cost data for 140 four-digit SIC industries in our sample. This is a labor-intensive task, but the payoff is an enhanced precision in assigning pollution intensity to the production activities of multinational firms. This is, however, still not a perfect measure. Note that we do not need to assume that the multinational firms in the source and host countries have identical pollution intensity. Instead, what we need is a weaker assumption: the relative pollution intensity between the overseas activities of the two multinational firms (e.g.,

\footnotetext{
${ }^{4}$ The actual number in the regressions is smaller due to missing values of various explanatory variables.

${ }^{5}$ On the other hand, a recent survey of multinationals has indicated that in sixty-two percent of cases the development of environment, health and safety laws and regulations in the home country had motivated changes in company-wide environmental policies and programs (UNCTAD, 1992, p. 38).
} 
Dupont Poland and Nike Poland) is proportional to their pollution intensity at home (e.g. Dupont and Nike in the U.S.).

None of the previous papers in the literature has taken all of the above issues into account. In that sense, our approach represents a significant improvement in the ability to uncover the "dirty secret," if there is any, on the relationship between environmental protection in a host country and the size and nature of its inward FDI. Rather than keeping the suspense, we spell out the bottom line right now. With various improvements relative to the previous literature, we find some support for the "pollution haven" hypothesis. To be more precise, the best evidence comes when participation in international environmental treaties is used as a measure of a host country's environmental standard. In this case, there is some evidence that investment from pollutionintensive multinational firms as a share of total inward FDI is smaller for host countries with a higher environmental standard. However, these findings do not survive various extensions and robustness checks. Therefore, our overall message is a caution against drawing strong conclusions based on selective evidence.

The rest of the paper is structured as follows. In the next section, we describe the methodology and the data employed. Section III discusses the empirical results. The last section concludes.

\section{METHODOLOGY AND KEY VARIABLES}

\section{Empirical model}

Let $F D I_{j k}$ be a dummy for FDI from multinational firm $j$ to host country $k . F D I_{j k}$ takes the value of one if firm $j$ has established investment or has concrete plans to invest in host country $k$, and zero otherwise.

Our strategy is to estimate some variant of the following probit specification:

$$
\operatorname{Prob}\left[F D I_{j k}=1\right]=X_{j} \Gamma_{j}+H_{k} \Phi_{k}+Z_{j k} \Pi+\beta E_{k}+\gamma D_{j} E_{k}+e_{j k}
$$

where $X_{j}$ is a vector of variables describing the characteristics of firm $j ; H_{k}$ is a vector of variables describing the characteristics of host country $k$ other than its environmental standards; $Z_{j k}$ is a vector of variables describing the relationship between host country $k$ and the source country where firm $j$ originates from; and $\Gamma_{j,} \Phi_{k}$ and $\Pi$ are vectors of parameters with corresponding dimensions. $D_{j}$ is an index of firm $j$ 's pollution intensity or "dirtiness," and $E_{k}$ is an index of host country $k$ 's 
environmental standards, possibly adjusted by the strength of enforcement. $e_{j k}$ is an iid normally distributed error term.

The parameter $\beta$ captures a "volume effect:" a negative (or positive) $\beta$ implies that a stronger environmental protection in a host country tends to discourage (or encourage) inward FDI. The parameter $\gamma$ captures a "composition effect:" a negative (or positive) $\gamma$ implies that more (or less) pollution-intensive FDI would go to a host country with relatively weaker environmental standards. In other words, the "pollution haven" hypothesis can be represented by $\gamma<0$.

Crucial to our empirical strategy is to have plausible measures of pollution intensity $D_{j}$ by multinational firms and of the strength of environment protection by host countries, $E_{k}$. We will discuss the construction of these measures next.

\section{Measuring pollution intensity of 4-digit SIC industries}

We use two measures of pollution intensity of industries: one based on pollution emissions and one on abatement costs. ${ }^{6}$ The first measure has been compiled from the Toxics Release Inventory (TRI) data collected by the Environmental Protection Agency. TRI provides a comprehensive overview of toxic chemical pollution from manufacturing facilities in the United States. In 1997, the reportable TRI chemical list contained 576 individually listed chemicals and 28 chemical categories. The database contains information on releases of toxic substances into air, water, land and underground injections measured by weight. A median value of emissions for reporting facilities in each 4-digit SIC code was found and was normalized by the mean value of sales in that sector.

A histogram analysis of the pollution intensity (not reported to save space) indicates that the data are highly skewed. A very small number of observations are more than three standard deviations away from the mean. As we are not sure if this is caused by the outliers in the EPA data or genuine difference in pollution intensity, we adopt a simple transformation that would help us avoid the dominance of outliers in our subsequent statistical analyses. More precisely, the data on pollution was converted into a pollution intensity index taking on the values from 0 to 2 by using the following criteria: the index takes on the value of zero if emissions in all four categories (air, land, water and underground) are in the lowest 33 percentiles; the value of 2 if emissions in any category are in the top 33 percentiles; and finally, the value of 1 in all other cases.

\footnotetext{
${ }^{6}$ Note that Eskaland and Harrison (2000) also used this data to construct their measures of pollution intensity.
} 
The second measure, the abatement index, is based on the data on total pollution abatement expenditures as reported in the Manufacturers' Pollution Abatement Capital Expenditures and Operating Costs Survey (Census Bureau, 1994). First, we aggregated operating costs and capital expenditures related to pollution abatement. Then, we followed a similar procedure to that described above to obtain normalized median values for each SIC code. The abatement data was also converted into an index ranging from 0 (if the normalized value was below the $33^{\text {rd }}$ percentile) to 2 (if the value was above the $66^{\text {th }}$ percentile).

Both indices were calculated based on two 4-digit SIC codes that describe the operations of each firm in our sample. ${ }^{7}$ If the index values for the two industry codes differed, the higher value was used. Note that dropping all firms for which index values differed between the two SIC codes would not change the conclusions of the paper. For the purposes of illustration, Table 1 lists the classification of industries at the three digit SIC level. In the regressions, however, classification at the four digit level has been used.

The main drawback of both indices is that they are based on the U.S. data. Thus we are assuming that pollution intensity of facilities set up by American investors overseas is the same as that of U.S. facilities, or (perhaps a weaker assumption that) the pollution intensity of the overseas production of two firms is proportional to their pollution intensity at home.

Further, it may be argued that the total amount of pollutants emitted does not take into account the differences in toxicity risks associated with different substances. Thus, an industry emitting a large quantity of a relatively harmless substance would rank as a greater polluter than another industry emitting a small quantity of a very potent pollutant. However, Dasgupta et al. (1998) have shown that at the aggregate level, there is no significant variation in ranking of industries based on total emissions and toxicity risks.

\section{Strength of environmental standards and their enforcement}

We measure the strength of environmental protection of the host countries in several different ways, which include:

(a) Participation in international treaties.

Treaties $=$ participation in international treaties. Five international treaties were developed by the Economic Commission for Europe during the past twenty-one years. We take into account four 
treaties that came into effect before or during the time relevant for our data set (i.e., before 1995). These are: the Convention on Long-range Transboundary Air Pollution, the Convention on Environmental Impact Assessment in a Transboundary Context, the Convention on the Transboundary Effects of Industrial Accidents, and the Convention on the Protection and Use of Transboundary Water-courses and International Lakes. The information on treaties comes from the United Nations Economic Commission for Europe. An index is created by awarding each country 1 point for ratifying each treaty prior to 1996 and 0.5 point for signing each treaty before 1996 or ratifying it after that time. Thus, the index can range from 0 to 4.

Mindful that participation in treaties and enforcement on the ground are not the same thing, we also wish to construct measures that adjust for possible strength of enforcement. Since active NGO movement tends to exert pressure on the government to enforce environmental regulation, we adjust for enforcement strength by making use of information on the number of environmentally oriented NGOs in a host country. Thus,

Enforcement-adjusted treaty index $=$ Treaties $*$ number of environmental NGOs per million people in country $k$.

The figures on NGOs come from OECD (1999, p. 47).

(b) Quality of air and water ambient and emission standards

Standards $=$ index of air and water ambient and emission standards in country $k$, which ranges from 1 denoting the weakest standards to 3 denoting the strongest. This index reflects laws on the books but not their enforcement. The source is EBRD (1997).

Similar to the previous measure, we also construct an enforcement-adjusted standard index as

$$
\text { Enforcement-adjusted standard index }=\text { Standards } * \text { number of environmental NGOs per }
$$
million people in country $k$

(c) Observed actual reduction in various pollutants

\footnotetext{
${ }^{7}$ Note that Worldscope database, from which we obtained firm SIC codes, reports up to nine 4 digit SIC codes for each firm ranked in order of importance. We used the first two.
} 
For three major pollutants (water pollutants, lead, $\mathrm{CO}_{2}$ ), we have collected data on actual observed percentage reduction in a number of transition economies. These might be viewed as result-based, enforcement-effort-adjusted, alternative measures of the strength of the environmental standard in the countries..

Water $=$ percentage reduction in emissions of organic water pollutants between 1990 and 1994. The emissions levels, from which the reduction has been calculated, come from the World Development Indicators database and are measured in terms of biochemical oxygen demand, which refers to the amount of oxygen that bacteria in water will consume in breaking down waste.

Lead $=$ percentage reduction in total lead emissions between 1990 and 1996. Source: OECD (1999, p. 47).

$\mathrm{CO}_{2}=$ percentage reduction in $\mathrm{CO}_{2}$ emissions between 1992 and 1995, calculated using figures from the World Development Indicators database.

Since changes in emissions of lead and $\mathrm{CO}_{2}$ may be largely due to changes in output, we make an adjustment to take it into account. Namely, we define two additional variables:

Reduction in Lead Emissions Adjusted for Changes in GDP = percentage reduction in total lead emissions plus percentage change in GDP during the corresponding period.

Reduction in $\mathrm{CO}_{2}$ Emissions Adjusted for Changes in $\mathrm{GDP}=$ percentage reduction in $\mathrm{CO}_{2}$ emissions plus percentage change in GDP during the corresponding period.

Variables Treaties and Standards reflect environmental standards on the book. Adjusted Treaties and Adjusted Standards are standards on the book adjusted for the strength of enforcement. The last five variables reflect the actual progress that has been made in lowering pollution emissions, thus they capture the combination of laws and their implementation.

All measures are standardized to have a zero mean and the standard deviation equal to unity. All measures are listed in Table 2. Summary statistics are presented in Table 3a, while correlations can be found in Table $3 \mathrm{~b}$.

\section{Measuring corruption in host countries}

Corruption, by its very nature, is difficult to measure. Most of the available indices are based on subjective perceptions from surveys of firms or individuals. Wei (2000b) discusses the relative merits and drawbacks of four types of corruption measures. Many of them do not cover enough transition economies to be useful to us. Thus, we adopt a composite measure based on GCR 
and WDR corruption indices. The GCR Index is derived from the Global Competitiveness Report 1997 produced jointly by the Geneva-based World Economic Forum and Harvard Institute for International Development. The survey for the report was conducted in late 1996 on 2,827 firms in 58 countries. The GCR Survey asked respondents to rate the level of corruption in their country on a one-to-seven scale, based on the extent of "irregular, additional payments connected with imports and exports permits, business licenses, exchange controls, tax assessments, police protection or loan applications." The GCR Corruption Index is based on the country average of the individual ratings.

The WDR Index comes from a 1996 World Bank survey of 3,866 firms in 73 countries conducted in preparation for the World Development Report 1997. Question 14 of that survey asks: "Is it common for firms in my line of business to have to pay some irregular, 'additional' payments to get things done?" The respondents were asked to rate the level of corruption on a one-to-six scale. The WDR corruption index is based on the country average of the individual answers. ${ }^{8}$

For both corruption indices, the original sources are such that a higher number implies lower corruption. To avoid awkwardness in interpretation, they are re-scaled in this paper so that a high number now implies high corruption.

Each measure covers a different subset of countries for which we have investment data, thus we use a composite corruption index derived by Wei (2000b). Since both indices come from surveys with similar methodologies and similar questions and are highly correlated (0.83), Wei combined them using the following procedure: (1) use GCR as the benchmark; (2) compute the ratio of GCR to WDR for all countries that are available in both GCR and the WDR; and (3) for those countries that are covered by WDR but not GCR (which is relatively rare), convert the WDR rating into the GCR scale by using the ratio in (2).

\section{Other variables}

Following the existing literature on determinants of FDI, our regressions also include proxies for market size (GDP), labor costs (GDP per capita) and corporate tax rate. ${ }^{9}$

The dependent variable comes from a unique firm-level data set based on the EBRD Foreign Investment Survey conducted in January 1995. A brief questionnaire was sent to about 9,500 firms from all over the world asking them about their planned or undertaken investment projects in

\footnotetext{
${ }^{8}$ This corruption measure was used, for instance, in Smarzynska and Wei (2000).

${ }^{9}$ For a review of the literature on FDI determinants see Caves (1982) and Froot (1993).
} 
Eastern Europe and the former Soviet Union. ${ }^{10}$ Additional information about the type of the project was requested. The criterion for including a firm in the survey was a firm's listing in a commercial database Worldscope, which provides detailed financial statements and business descriptions for public companies located in more than fifty countries. Sending the questionnaire to all firms listed assured that all major public companies in the world were included. Responses were obtained from 1,405 firms. ${ }^{11}$ Unfortunately, the survey did not ask about the time when each investment was undertaken. However, since the magnitude of FDI inflows into the region was marginal before 1989, the information collected pertains mostly to the period $1989-94 .{ }^{12}$

Our empirical analysis focuses on investment in manufacturing facilities since investment in service sectors or in distribution alone is not likely to have a significant environmental impact. As the objective of this study is to explore the impact of government policies on the magnitude and nature of FDI inflows, firms in the oil, gas and coal sector, which are likely to be attracted to natural resource endowments, are excluded from the estimations.

Information on firm characteristics, such as size and $\mathrm{R} \& \mathrm{D}$ intensity, is from Worldscope. The proxy for regional experience comes from the survey. The distance between the source and host countries has been calculated by the authors. See Appendix I for a detailed description of all variables.

\section{ESTIMATION RESULTS}

\section{Basic Regressions}

We begin the test of the "pollution haven" hypothesis with regressions employing participation in international treaties as a proxy for environmental standards in a host country. The results, presented in terms of marginal effects, can be found in Table 4. As stated in the last section, the coefficient on the environmental regime (labeled Env Regime) captures a volume effect - the (marginal) effect of the strength of environmental protection in a host country on the overall volume of inward FDI. The coefficient on the product of the host country's environmental regime and the

\footnotetext{
${ }^{10}$ The source countries in the sample listed in order of importance include: United Kingdom, United States, Japan, Canada, Germany, France, Finland, Switzerland, South Africa, Sweden, Ireland, Australia, Norway, Italy, Malaysia, Netherlands, Belgium, Denmark, New Zealand, Austria, Singapore, Portugal, Argentina, Colombia, Greece, Philippines, South Korea and Hong Kong, China.

${ }^{11} 117$ of the survey respondents were chosen for in-depth interviews whose results are discussed in Lankes and Venables (1996).

${ }^{12}$ Eastern Europe and the Soviet Union were virtually closed to foreign investment before 1989 (see Meyer, 1995; Dunning and Rojec, 1993; Hunya, 1997).
} 
investing firm's pollution intensity captures a composition effect - whether stronger environmental protection discourages the investment from more polluting industries by a greater amount.

The results provide support for the composition effect but little evidence of the volume effect. In the first column, we find that the interaction term between environmental regime and the emission index bears a negative and statistically significant sign, as predicted by the hypothesis. Environmental standards alone, however, do not have a statistically significant effect on the probability of investment.

The volume effect (measured by a host country's environmental standards) and the composition effect (measured by the product of a host country's standard and a multinational firm's pollution intensity) are correlated. To give the "pollution haven" hypothesis the maximum benefit of doubt, we re-estimate the first regression dropping the measure of environmental standards but leaving its interaction with investor pollution intensity. The interaction terms remains significant.

As the introductory section stated, omission of the corruption variable in the previous empirical papers may have been one reason why host country environmental standards did not appear to matter for inward FDI. To make an assessment of this possibility, we estimate a model in which host country corruption is dropped (but both environmental standards and the interaction terms are included). As we can see in the third column, the interaction term gives evidence of the composition effect but no volume effect is present (i.e., environmental standards remain insignificant).

When we take into account enforcement of the international treaties (columns 4-6), again we find support for the composition effect but mixed evidence on the volume effect. Recall that enforcement is proxied by the number of environmental NGOs in a host country relative to the population size. The NGO variable is not available for all countries, and thus it restricts our sample to Eastern Europe and the Baltic republics (Latvia, Lithuania and Estonia). ${ }^{13}$ Overall, the results indicate that foreign investors in polluting industries are more likely to enter countries with less stringent environmental standards, but this is not the case for foreign investors in general.

The other variables have the expected signs. We find that larger and less R\&D-intensive firms are more likely to undertake FDI. ${ }^{14}$ This is also the case for investors with previous regional experience. As far as host country characteristics are concerned, the data indicate that large countries and those located close to the investor's home country are more attractive to FDI. On the

\footnotetext{
${ }^{13}$ The number of active NGOs could be affected by the extent of political freedom. This is, however, unlikely to be an issue in the subsample of transition economies for which are using the NGO data.
} 
other hand, high corporate taxes and a greater incidence of corruption discourage foreign investors. GDP per capita does not appear to be significant in most regressions.

\section{Robustness Checks and Extensions}

To check the robustness of our findings, we presents results from regressions using alternative measures of environmental regulation (Table 5). No support is found for the "pollution haven" when the raw EBRD's rating of the air and water standard is used, but there is some evidence in its favor if the EBRD rating is adjusted for enforcement. Further, there is no support for the hypothesis when reductions in emissions are employed as a proxy for environmental regime. This is the case for the raw reduction figures as well as for reductions adjusted for output changes. Thus, the empirical evidence of the "pollution haven" hypothesis is not robust to using different proxies for environmental standards in host countries.

As another robustness test, we re-estimate the model using abatement cost index to capture a firm's pollution intensity (Table 6). When this change is made, the evidence in favor of the hypothesis disappears almost completely. The interaction term is not significant in any of the seven regressions, indicating the there is no composition effect. The volume effect can be detected only in one out of seven cases.

Since our measures of investor pollution intensity have been calculated using the U.S. data, one could argue that this calls for limiting our sample to U.S. firms only. When we re-estimate our model on this subsample (see Table 7), the evidence in favor of "pollution haven" hypothesis is fairly weak. The coefficient of environmental regulation is significant and negative only in two cases and none of the interaction terms is negative and significant. Note that in this subsample tax rates do not have a significant effect on investment decision, which may be due to tax credits U.S. companies receive for tax payments made abroad.

Further, we re-estimate our model employing the Neumann index as a measure of corruption incidence in host countries. The regression results, presented in Table 8a, give some support to the composition effect but no to the volume effect. As before, the composition effect is present when environmental regime is proxied by participation in international treaties and emission standards (both laws on books and laws adjusted for enforcement), but not when reduction in emissions are employed.

\footnotetext{
${ }^{14}$ This is consistent with the findings of Smarzynska (1999).
} 
Finally, Table $8 \mathrm{~b}$ presents the results with both Neumann index and abatement cost index. In this case, hardly any support is found for the hypothesis.

We have performed further robustness checks that are not presented here. For instance, we narrowed the sample to include only firms in highly polluting industries (emissions or abatement index equal to two) and estimated the original model as well as the model without interaction terms. The results produced gave very little support to the "pollution haven" hypothesis.

As an alternative way of adjusting the measures of environmental standards for enforcement, we divided them by the corruption index. This adjustment, however, did not alter the qualitative results since the coefficients of interest remained insignificant in almost all the regressions.

Finally, we restricted our sample to include only firms that undertook at least one investment in the region, thus limiting the number of zeros on the left-hand side. Again, the results led us to the same conclusions.

Summing up, despite our best efforts we were unable to find more than a weak support for the "pollution haven" hypothesis. Our data indicate that host country environmental standards have very little impact on FDI inflows both in terms of the volume and in terms of composition. We do not find robust evidence of foreign investment in pollution-intensive industries flocking to countries with weak environmental regimes.

\section{CONCLUDING REMARKS}

This paper makes an effort in four different areas to enhance our ability to detect the possible "dirty secret" that multinational firms flock to countries with weak environmental protection and that this is particularly the case for more pollution-intensive industries. Our effort includes (a) taking into explicit account the effect of host country corruption, (b) using firm-level rather than country- or industry-level data, (c) employing a variety of measures that capture the strength of environmental protection in host countries, and (d) constructing a measure of pollution intensity at the 4-digit industry level.

With these improvements, we find some support for the "pollution haven" hypothesis. In particular, the most supportive evidence comes when a country's environmental standard is measured by its participation in international environmental treaties. In this case, investment from pollution-intensive multinational firms as a share of total inward FDI is lower for host countries 
with a higher environmental standard. However, the support for the "pollution haven" hypothesis is not robust to various sensitivity checks.

Our findings are still subject to caveats. We have a relatively small number of host countries so the variation of environmental protection may be limited. The measures of pollution intensity and of the strength of environmental protection can still be too noisy to allow us to obtain precise estimates. Future work will, hopefully, improves on these dimensions. 


\section{BIBLIOGRAPHY}

Becker, Randy and Vernon Henderson. 2000. "Effects of Air Quality Regulation on Polluting Industries," Journal of Political Economy, 108(2): 379-421.

Caves, R., 1982, Multinational Enterprise and Economic Analysis. Cambridge University Press: New York.

Census Bureau. 1994. "Pollution Abatement Costs and Expenditures: 1994," Current Industrial Reports. U.S. Department of Commerce, ESA.

Damania, Richard, Per G. Fredriksson and John A. List. 2000. "Trade Liberalization, Corruption and Environmental Policy Formation: Theory and Evidence," CIES Discussion Paper No. 47. Adelaide University: Australia.

Dasgupta, S., Laplante, B. and C. Meisner. 1998. "Accounting for toxicity risks in pollution control: Does it matter? World Bank Policy Research Working Paper No. 2002.

Dean, Judith. 1992. Trade and Environment: A Survey of the Literature. Policy Research Working Paper World Development Report No. 966. The World Bank.

Dunning, John H and Matija Rojec. 1993. Foreign Privatization in Central \& Eastern Europe. CEEPN: Ljubljana, Slovenia.

Froot, Kenneth, 1993, Foreign Direct Investment, Chicago: University of Chicago Press.

Eskeland, Gunnar and Ann Harrison. 1997. "Moving to greener pastures? Multinationals and the pollution-haven hypothesis," The World Bank Policy Research Working Paper No. 1744.

European Bank for Reconstruction and Development. 1997. Transition Report. London.

Hines, James, 1995, "Forbidden payment: Foreign Bribery and American Business After 1977," NBER Working Paper 5266, September.

Hunya, Gabor. 1997. "Large privatisation, restructuring and foreign direct investment" in Salvatore Zecchini, ed., Lessons from the Economic Transition. Central and Eastern Europe in the 1990s. Kluwer Academic Publishers: Dordrecht, Boston and London. 275-300.

Kaufmann, Daniel, and Shang-Jin Wei. 1999. "Does 'Grease Payment' Speed Up the Wheels of Commerce?” NBER Working Paper 7093, April.

Lankes, Hans-Peter and Anthony J. Venables, 1996, "Foreign direct investment in economic transition: The changing pattern of investments," Economics of Transition. 4: 331-347.

Letchumanan, Raman and Fumio Kodama. 2000. "Reconciling the conflict between the "pollutionhaven' hypothesis and an emerging trajectory of international technology transfer" Research Policy, 29:59-79.

Levinson, Arik. 1996. "Environmental regulation and manufacturers' location choices: Evidence from the Census of Manufactures" Journal of Public Economics, 62:5-29.

Meyer, Klaus. 1995. "Direct Foreign Investment in Eastern Europe. The Role of Labor Costs," Comparative Economic Studies. 37(3): 69-88.

OECD. 1999. Environment in the Transition to a Market Economy. Progress in Central and Eastern Europe and the New Independent States. OECD: Paris. 
Smarzynska, Beata. 1999. "Composition of foreign direct investment and protection of intellectual property rights in transition economies” CEPR Working Paper 2228, September.

Smarzynska, Beata and Shang-Jin Wei. 2000. "Corruption and composition of foreign direct investment: Firm level evidence” NBER Working Paper 7969, October.

UNCTAD. 1993. Environmental Management in Transnational Corporations. United Nations: New York.

Wei, Shang-Jin, 1997, "Why is Corruption So Much More Taxing Than Taxes? Arbitrariness Kills.” NBER Working Paper 6255, November.

Wei, Shang-Jin, 2000a, "How Taxing is Corruption on International Investors?" Review of Economics and Statistics, February, 82(1): 1-11.

Wei, Shang-Jin. 2000b. "Local Corruption and Global Capital Flows," Brookings Papers on Economic Activity, No. 2.

Wheeler, David, 2000, "Racing to the Bottom? Foreign Investment and Air Quality in Developing Countries." Unpublished working paper, The World Bank, November.

Xing, Y. and C. Kolstad. 1998. "Do Lax Environmental Regulations Attract Foreign Investment?" Working Paper No. 28-98. University of California Santa Barbara.

Zarsky, Lyuba. 1999. "Havens, Halos and Spaghetti: Untangling the Evidence about Foreign Direct Investment and the Environment" in Foreign Direct Investment and the Environment. OECD. p. 47-74. 


\section{APPENDIX I}

Firm specific variables used in the empirical analysis come from Worldscope, which is a commercial database providing detailed financial statements, business descriptions, and historical pricing information on thousands of public companies located in more than fifty countries. They pertain to 1993 or the closest year for which the information was available and refer to worldwide operations of each firm. Below we present a more detailed description of the variables.

Firm size: measured by a firm's sales in millions of U.S. dollars

$>$ Firm R\&D intensity: measured by $\mathrm{R} \& \mathrm{D}$ expenditure as a percentage of net sales

$>$ Regional experience: a dummy variable taking on the value of one if a firm had a trading relationship with the region before 1990, zero otherwise. Source: EBRD survey

Distance: logarithm of distance in kilometers between the capital cities. The primary source is Rudloff (1981), supplemented by Pearce and Smith (1984). In the case of following countries the average distance from the main cities was used: Argentina (Buenos Aires, Cordoba, Rosario), Australia (Canberra, Sydney, Melbourne), Canada (Toronto, Vancouver, Montreal), Russia (Moscow, St. Petersburg, Nizhni Novogorod). The data for Nizhni Novogorod is from http://www.unn.runnet.ru/nn/whereis.htm. For the United States Kansas City, Missouri was used, for Netherlands De Bilt, Slovakia Poprad, Switzerland Zurich. Distances between Taiwan and other countries are from Shang-Jin Wei’s NBER web site: www.nber.org/ wei.

> Pollution emissions index: 1997 pollution emission data by facility comes from the EPA website (www.epa.gov/triexplorer/facility.htm). The volume of emissions is measured by weight. Four-digit SIC codes by facility were taken from a CD-ROM provided by the EPA, which is labeled "RY 1998 TRI Database Files." The data can be found in Section 2.12 TRI_Facility_SIC_History. The information on all facilities that reported both an SIC code and emissions were taken into account. The SIC code and the emissions data were matched for each facility. If a facility reported more than one SIC code, each unique facility and SIC pair was treated as an individual observation. The value of emissions for each observation was divided by the number of SIC codes reported for the facility. The data was then regrouped by SIC code and the median of all observations for a particular 4 digit SIC code was calculated for each emissions category (air, land, water, underground).

The emissions data were then normalized by the average shipping volume in the industry. The information on shipping volumes comes from the 1997 Economic Census CD- 
ROM. The average shipping volume was found by dividing the 1997 value of sales, shipments and receipts (given in thousands of dollars) by the number of establishments reporting for that SIC code. If data on shipping volumes were not available for a particular SIC code, that code was dropped. The data were then converted into an index as described in Section II

$>$ Abatement index: based on the 1994 data on total pollution abatement expenditures as reported in the Manufacturers' Pollution Abatement Capital Expenditures and Operating Costs Survey (PACE). Source: Census Bureau (1994). Total pollution abatement expenditures are equal to the sum of operating costs and capital expenditures related to pollution abatement. A similar procedure to that followed in the case of emissions index was used to obtain normalized median values for each 4 digit SIC code. Then the data was converted into an index ranging from 0 (if the normalized value was below the $33^{\text {rd }}$ percentile) to 2 (if the value was above the $66^{\text {th }}$ percentile)

GDP and GDP per capita: data for 1993. Source: EBRD (1994)

$>G C R / W D R$ : see the description in Section II.

$>$ Corporate tax rate: in percentages; if several rates apply, the highest one was used. Source: PriceWaterhousePaineWebber

$>$ Index of Air and Water Ambient and Emission (Effluent) Standards: grades how closely the national environmental legislation approximates EU standards. Source: EBRD (1997).

\begin{tabular}{|c|l|}
\hline Value of index & Description \\
\hline 1 & $\begin{array}{l}\text { Maximum permissible concentration (MPC) system in place, broadly based } \\
\text { on the former Soviet system }\end{array}$ \\
\hline 2 & $\begin{array}{l}\text { New system is being introduced, either as an evolution of MPC or in order to } \\
\text { meet EU requirements }\end{array}$ \\
\hline 3 & $\begin{array}{l}\text { Essentially new standards system is in place, often following EU } \\
\text { requirements }\end{array}$ \\
\hline
\end{tabular}

Participation in key international treaties. These treaties are: the Convention on Long-range Transboundary Air Pollution, the Convention on Environmental Impact Assessment in a Transboundary Context, the Convention on the Transboundary Effects of Industrial Accidents, and the Convention on the Protection and Use of Transboundary Water-courses and International Lakes. The information on treaties comes from the United Nations Economic Commission for Europe. An index is created by awarding each country 1 point for ratifying the treaty prior to 1996 and 0.5 point for signing each treaty before 1996 or ratifying it after that time. Thus, the index can range from 0 to 4 . 
Number of Environmental NGOs per Million Population: data for 1996. Source: OECD (1999, p. 47)

$>$ Reduction in Lead Emissions: Percentage reduction in total lead emissions between 1990 and 1996. Source: OECD (1999, p. 47)

$>$ Reduction in Lead Emissions Adjusted for Changes in GDP: Percentage reduction in total lead emissions plus percentage change in GDP during the corresponding period.

$>$ Reduction in Water Pollutant Emissions: percentage reduction in emissions of organic water pollutants that took place between 1990 and 1994 (measured in kg per day per worker). The emissions levels, from which the reduction has been calculated, come from the World Development Indicators database and are measured in terms of biochemical oxygen demand, which refers to the amount of oxygen that bacteria in water will consume in breaking down waste.

$>$ Reduction in $\mathrm{CO}_{2}$ Emissions: percentage reduction in $\mathrm{CO}_{2}$ emissions between 1992 and 1995, calculated using figures from the World Development Indicators database. The original figures refer to industrial emissions measured in metric tons per capita.

$>$ Reduction in $\mathrm{CO}_{2}$ Emissions Adjusted for Changes in GDP: percentage reduction in $\mathrm{CO}_{2}$ emissions plus percentage change in GDP during the corresponding period.

Distance, GDP, GDP per capita and firm size are used in the log form. 
Table 1. Classification of 3-digit SIC sectors by pollution intensity

\begin{tabular}{|c|c|c|c|}
\hline \multicolumn{4}{|c|}{ High Pollution } \\
\hline $102 \sim$ & Copper ores & $276 \#$ & Manifold business forms \\
\hline $109 \sim$ & Miscellaneous metal ores & $278 \sim$ & Blankbooks and bookbinding \\
\hline $131 \sim$ & Crude petroleum and natural gas & $282 *$ & Plastics materials and synthetics \\
\hline $132 \sim$ & Natural gas liquids & $283 *$ & Drugs \\
\hline $172 \sim$ & $\begin{array}{l}\text { Painting and paper hanging special trade } \\
\text { contractors }\end{array}$ & $284 *$ & Soaps, cleaners, and toilet goods \\
\hline $175 \sim$ & $\begin{array}{l}\text { Carpentry and floor work special trade } \\
\text { contractors }\end{array}$ & $287 *$ & Agricultural chemicals \\
\hline $179 \sim$ & Miscellaneous special trade contractors & 308 & Miscellaneous plastics products, n.e.c. \\
\hline $205 \#$ & Bakery products & $314 \sim$ & Footwear, except rubber \\
\hline 206 \# & Sugar and confectionery products & $325 \sim$ & Structural clay products \\
\hline $224 \sim$ & Narrow fabric mills & $326 *$ & Pottery and related products \\
\hline $226 *$ & Textile finishing, except wool & $327 *$ & Concrete, gypsum, and plaster products \\
\hline $235 \sim$ & Hats, caps, and millinery & $328 \sim$ & Cut stone and stone products \\
\hline $239 \sim$ & Miscellaneous fabricated textile products & $329 *$ & $\begin{array}{l}\text { Miscellaneous nonmetallic mineral } \\
\text { products }\end{array}$ \\
\hline $241^{\wedge}$ & Logging & $331 *$ & Blast furnace and basic steel products \\
\hline 242 & Sawmills and planing mills & $332 *$ & Iron and steel foundries \\
\hline 243 & $\begin{array}{l}\text { Millwork, plywood, and structural } \\
\text { members }\end{array}$ & 333 \# & Primary nonferrous metals \\
\hline 249 & Miscellaneous wood products & 341 \# & Metal cans and shipping containers \\
\hline 251 & Household furniture & $344 *$ & Fabricated structural metal products \\
\hline $252 \#$ & Office furniture & $345 *$ & Screw machine products, bolts, etc. \\
\hline 254 & Partitions and fixtures & $347 *$ & Metal services, n.e.c. \\
\hline $259 \sim$ & Miscellaneous furniture and fixtures & $354 *$ & Metalworking machinery \\
\hline 261 \# & Pulp mills & $367 *$ & Electronic components and accessories \\
\hline $262 \#$ & Paper mills & 373 & Ship and boat building and repairing \\
\hline $263 \#$ & Paperboard mills & $385 \sim$ & Ophthalmic goods \\
\hline $272 \sim$ & Periodicals & $387 \sim$ & Watches, clocks, watchcases, and parts \\
\hline 273 \# & Books & $393 \sim$ & Musical instruments \\
\hline 275 & Commercial printing & & \\
\hline
\end{tabular}

\# emission but in another abatement category

* abatement but in another emission category

$\wedge$ only abatement data was available

$\sim$ only emission data was available 


\begin{tabular}{|c|c|c|c|}
\hline \multicolumn{2}{|r|}{$\begin{array}{r}\text { Low Pollution } \\
\end{array}$} & \multicolumn{2}{|r|}{ Medium Pollution } \\
\hline $142 \sim$ & Crushed and broken stone, including riprap & 201 & Meat products \\
\hline $154 \sim$ & $\begin{array}{l}\text { General building contractors-nonresidential } \\
\text { buildings }\end{array}$ & $204 *$ & Grain mill products \\
\hline $202 \sim$ & Dairy products & $205 *$ & Bakery products \\
\hline 204 \# & Grain mill products & $214 \#$ & Tobacco stemming and redrying \\
\hline $206^{*}$ & Sugar and confectionery products & $221 \#$ & Broadwoven fabric mills, cotton \\
\hline $211 \sim$ & Cigarettes & $226 \#$ & Textile finishing, except wool \\
\hline $214 *$ & Tobacco stemming and redrying & $245 \sim$ & Wood buildings and mobile homes \\
\hline $221 *$ & Broadwoven fabric mills, cotton & $252 *$ & Office furniture \\
\hline 222 & Broadwoven fabric mills, manmade fiber and silk & $253 \sim$ & Public building and related furniture \\
\hline $223 \sim$ & Broadwoven fabric mills, wool & $262 *$ & Paper mills \\
\hline $227 \sim$ & Carpets and rugs & $263 *$ & Paperboard mills \\
\hline $232 \sim$ & Men's and boys' furnishings & $265 \#$ & Paperboard containers and boxes \\
\hline $261 *$ & Pulp mills & $271^{\wedge}$ & Newspapers \\
\hline $265 *$ & Paperboard containers and boxes & $282 \#$ & Plastics materials and synthetics \\
\hline $273 *$ & Books & 285 & Paints and allied products \\
\hline $274 \sim$ & Miscellaneous publishing & $287 \#$ & Agricultural chemicals \\
\hline $276^{*}$ & Manifold business forms & 291 & Petroleum refining \\
\hline $277 \sim$ & Greeting cards & $295 *$ & Asphalt paving and roofing materials \\
\hline $279 \sim$ & Printing trade services & 306 & Fabricated rubber products, n.e.c. \\
\hline 283 \# & Drugs & 311 & Leather tanning and finishing \\
\hline $284 \#$ & Soaps, cleaners, and toilet goods & $321 \sim$ & Flat glass \\
\hline 295 \# & Asphalt paving and roofing materials & 322 & Glass and glassware, pressed or blown \\
\hline 299 & Miscellaneous petroleum and coal products & 323 & Products of purchased glass \\
\hline 301 & Tires and inner tubes & 324 & Cement, hydraulic \\
\hline $302 \sim$ & Rubber and plastics footwear & $326 \#$ & Pottery and related products \\
\hline 305 & Hose and belting and gaskets and packing & $327 \#$ & Concrete, gypsum, and plaster products \\
\hline $317 \sim$ & Handbags and personal leather goods & $329 \#$ & Miscellaneous nonmetallic mineral products \\
\hline $331 \#$ & Blast furnace and basic steel products & $332 \#$ & Iron and steel foundries \\
\hline $333 *$ & Primary nonferrous metals & $336 *$ & Nonferrous foundries (castings) \\
\hline 334 & Secondary nonferrous metals & 339 & Miscellaneous primary metal products \\
\hline 335 & Nonferrous rolling and drawing & $344 \#$ & Fabricated structural metal products \\
\hline 336 \# & Nonferrous foundries (castings) & $346 *$ & Metal forgings and stampings \\
\hline $341 *$ & Metal cans and shipping containers & $347 \#$ & Metal services, n.e.c. \\
\hline 343 & Plumbing and heating, except electric & $348 *$ & Ordnance and accessories, n.e.c. \\
\hline 345 \# & Screw machine products, bolts, etc. & $353 \#$ & Construction and related machinery \\
\hline 346 \# & Metal forgings and stampings & $354 \#$ & Metalworking machinery \\
\hline 348 \# & Ordnance and accessories, n.e.c. & $356 *$ & General industrial machinery \\
\hline $353 *$ & Construction and related machinery & 358 & Refrigeration and service machinery \\
\hline 356 \# & General industrial machinery & $359 \sim$ & Industrial machinery, n.e.c. \\
\hline & Electric distribution equipment & 362 & Electrical industrial apparatus \\
\hline $364 \#$ & Electric lighting and wiring equipment & $364 *$ & Electric lighting and wiring equipment \\
\hline & Communications equipment & $365 \sim$ & Household audio and video equipment \\
\hline 367 \# & Electronic components and accessories & $372 \#$ & Aircraft and parts \\
\hline $372 *$ & Aircraft and parts & 374 & Railroad equipment \\
\hline & Guided missiles, space vehicles, parts & $382 \sim$ & Measuring and controlling devices \\
\hline $381 \sim$ & Search and navigation equipment & 386 & Photographic equipment and supplies \\
\hline & Jewelry, silverware, and plated ware & $395 \#$ & Pens, pencils, office, and art supplies \\
\hline $395 *$ & Pens, pencils, office, and art supplies & & \\
\hline
\end{tabular}


Table 2. Measures of environmental standards and corruption

\begin{tabular}{|c|c|c|c|c|c|c|c|c|}
\hline & Corru & tion & & & & & uction in emissions & \\
\hline & GCR/WDR & Neumann & Treaties & Standards & NGOs & Lead & Water pollutants & $\mathrm{CO}_{2}$ \\
\hline Armenia & 4.5 & 6 & 1.5 & 1 & & & -136.4 & 8.4 \\
\hline Azerbaijan & 5.5 & 6 & 1 & 1 & & & -13.3 & 32.6 \\
\hline Belarus & 5 & 4 & 1.5 & 1 & & 97 & & 34.5 \\
\hline Bulgaria & 5.5 & 4 & 3.5 & 1 & 11.8 & 42 & -27.3 & -12.1 \\
\hline Croatia & & 4 & 2.5 & 2 & 39 & 39 & -6.7 & -7.7 \\
\hline Czech Rep. & 3.3 & 4 & 2.5 & 3 & 49.5 & & -7.7 & 8.8 \\
\hline Estonia & 2.6 & 2 & 2.5 & 2 & 21.9 & 72 & & 23.0 \\
\hline Georgia & 5 & 4 & 0.5 & 1 & & & & 84.8 \\
\hline Hungary & 3.9 & 6 & 3.5 & 3 & 69.1 & & -12.5 & -3.8 \\
\hline Kazakhstan & 5.1 & 4 & 2 & 1 & & 15 & & 28.0 \\
\hline Kyrgyzstan & 4.9 & 4 & 0.5 & 1 & & & -33.3 & 48.7 \\
\hline Latvia & 4.6 & 4 & 2.5 & 2 & 22.2 & & -41.7 & 24.6 \\
\hline Lithuania & 3.9 & 0 & 2.5 & 1 & 21.3 & 62 & -25.0 & 31.4 \\
\hline Macedonia & & 8 & 1 & 1 & 36 & & 5.6 & 1.0 \\
\hline Moldova & 5 & & 4 & 1 & & & -80.0 & 46.9 \\
\hline Poland & 4.6 & 4 & 2.5 & 3 & 15.5 & 27 & -14.3 & -0.6 \\
\hline Romania & & 6 & 2.5 & 2 & 9 & & -16.7 & 1.3 \\
\hline Russia & 5.3 & 8 & 3.5 & 1 & & & & 13.6 \\
\hline Slovak Rep. & 3.6 & 4 & 2 & 2 & 26.1 & 45 & -7.7 & 13.6 \\
\hline Slovenia & & 2 & 2 & 2 & 57 & & 0.0 & -16.8 \\
\hline Tajikistan & & 4 & 0 & 1 & & & & 76.0 \\
\hline Turkmenistan & & 4 & 0 & 1 & & & & -6.5 \\
\hline Ukraine & 4.3 & 4 & 2 & 1 & & 75 & -7.1 & 28.9 \\
\hline Uzbekistan & 5.2 & 4 & 0 & 1 & & 50 & & 18.5 \\
\hline
\end{tabular}


Table 3a. Summary statistics

\begin{tabular}{lccc}
\hline \multicolumn{1}{c}{ Variable } & No. of Obs. & Mean & Std. Dev. \\
\hline ln (Firm size) & 534 & 13.4 & 1.9 \\
R\&D-intensity & 534 & 2.4 & 3.6 \\
Regional experience & 534 & 0.3 & 0.5 \\
Emissions index & 559 & 0.9 & 0.8 \\
Abatement index & 448 & 1.2 & 0.8 \\
ln (Distance) & 11,726 & 8.2 & 0.9 \\
ln (GDP) & 24 & 8.7 & 1.6 \\
ln (GDP per capita) & 24 & 6.6 & 1.1 \\
Tax rate & 22 & 29.5 & 6.4 \\
Corruption GCR/WDR index & 18 & 4.5 & 0.8 \\
Corruption Neumann index & 23 & 5.3 & 1.8 \\
Participation in international treaties & 24 & 1.9 & 1.2 \\
Emissions standards & 24 & 1.5 & 0.7 \\
Reduction in CO ${ }_{2}$ emissions & 24 & 19.9 & 25.9 \\
Reduction in water pollution emissions & 17 & -26.5 & 35.6 \\
Reduction in lead emissions & 10 & 52.4 & 24.4 \\
No. of environmental NGOs per mn population & 12 & 31.5 & 18.9 \\
\hline
\end{tabular}


Table 3b. Correlations between country specific variables

\begin{tabular}{|c|c|c|c|c|c|c|c|c|c|c|c|c|c|}
\hline & $\ln (\mathrm{GDP})$ & $\ln$ (GDP p.c.) & Tax rate & Distance & GCR/WDR & Neumann & Treaties & Adj Treaties & Standards & Adj Standards & Lead & Water & $\mathrm{CO}_{2}$ \\
\hline $\ln (\mathrm{GDP})$ & 1.00 & & & & & & & & & & & & \\
\hline $\ln$ (GDP p.c.) & 0.71 & 1.00 & & & & & & & & & & & \\
\hline Tax rate & 0.27 & 0.00 & 1.00 & & & & & & & & & & \\
\hline Distance & -0.08 & -0.14 & 0.02 & 1.00 & & & & & & & & & \\
\hline GCR/WDR & -0.04 & -0.47 & 0.03 & 0.13 & 1.00 & & & & & & & & \\
\hline Neumann & 0.21 & -0.08 & -0.19 & 0.04 & 0.45 & 1.00 & & & & & & & \\
\hline Treaties & 0.53 & 0.53 & -0.01 & -0.14 & -0.20 & 0.03 & 1.00 & & & & & & \\
\hline Adj Treaties & 0.36 & 0.66 & -0.34 & -0.02 & -0.22 & 0.09 & 0.42 & 1.00 & & & & & \\
\hline Standards & 0.53 & 0.72 & 0.12 & -0.13 & -0.60 & -0.08 & 0.41 & 0.55 & 1.00 & & & & \\
\hline Adj Standards & 0.45 & 0.76 & -0.24 & -0.03 & -0.32 & 0.14 & 0.27 & 0.96 & 0.69 & 1.00 & & & \\
\hline Lead & -0.68 & -0.62 & -0.36 & -0.09 & -0.29 & -0.26 & -0.19 & 0.01 & -0.33 & -0.27 & 1.00 & & \\
\hline Water pollut. & 0.63 & 0.63 & 0.07 & -0.07 & -0.25 & -0.11 & -0.09 & 0.21 & 0.35 & 0.33 & 0.04 & 1.00 & \\
\hline $\mathrm{CO}_{2}$ & -0.56 & -0.73 & -0.04 & 0.09 & 0.19 & -0.15 & -0.37 & -0.28 & -0.44 & -0.29 & 0.54 & -0.30 & 1.00 \\
\hline
\end{tabular}


Table 4. Participation in international treaties

\begin{tabular}{|c|c|c|c|c|c|c|}
\hline \multirow[b]{2}{*}{ Firm size } & \multicolumn{3}{|c|}{ Treaties } & \multicolumn{3}{|c|}{ Enforcement Adjusted Treaties } \\
\hline & $\begin{array}{c}0.0063 * * * \\
(0.0008)\end{array}$ & $\begin{array}{c}0.0063 * * * \\
(0.0008)\end{array}$ & $\begin{array}{c}0.0062 * * * \\
(0.0009)\end{array}$ & $\begin{array}{c}0.0112 * * * \\
(0.0015)\end{array}$ & $\begin{array}{c}0.0117 * * * \\
(0.0016)\end{array}$ & $\begin{array}{c}0.0094 * * * \\
(0.0017)\end{array}$ \\
\hline R\&D-intensity & $\begin{array}{c}-0.0014 * * * \\
(0.0005)\end{array}$ & $\begin{array}{c}-0.0014 * * * \\
(0.0005)\end{array}$ & $\begin{array}{c}-0.0013 * * * \\
(0.0005)\end{array}$ & $\begin{array}{c}-0.0038 * * * \\
(0.0007)\end{array}$ & $\begin{array}{c}-0.0040 * * * \\
(0.0007)\end{array}$ & $\begin{array}{c}-0.0029 * * * \\
(0.0009)\end{array}$ \\
\hline Regional experience & $\begin{array}{l}0.0053 * * \\
(0.0024)\end{array}$ & $\begin{array}{c}0.0053 * * \\
(0.0024)\end{array}$ & $\begin{array}{c}0.0057 * * \\
(0.0023)\end{array}$ & $\begin{array}{c}0.0008 \\
(0.0023)\end{array}$ & $\begin{array}{c}0.0009 \\
(0.0024)\end{array}$ & $\begin{array}{c}0.0031 \\
(0.0031)\end{array}$ \\
\hline GDP & $\begin{array}{c}0.0088 * * * \\
(0.0016)\end{array}$ & $\begin{array}{c}0.0089 * * * \\
(0.0016)\end{array}$ & $\begin{array}{c}0.0088 * * * \\
(0.0011)\end{array}$ & $\begin{array}{c}0.0191 * * * \\
(0.0034)\end{array}$ & $\begin{array}{c}0.0212 * * * \\
(0.0042)\end{array}$ & $\begin{array}{c}0.0154 * * * \\
(0.0031)\end{array}$ \\
\hline GDP per capita & $\begin{array}{c}0.0014 \\
(0.0031)\end{array}$ & $\begin{array}{c}0.0016 \\
(0.0030)\end{array}$ & $\begin{array}{l}-0.0003 \\
(0.0019)\end{array}$ & $\begin{array}{c}0.0057 \\
(0.0121)\end{array}$ & $\begin{array}{l}-0.0082 \\
(0.0097)\end{array}$ & $\begin{array}{l}-0.0097^{*} \\
(0.0059)\end{array}$ \\
\hline Tax rate & $\begin{array}{l}-0.0003^{*} \\
(0.0002)\end{array}$ & $\begin{array}{c}-0.0003 * * \\
(0.0002)\end{array}$ & $\begin{array}{l}-0.0001 \\
(0.0002)\end{array}$ & $\begin{array}{c}-0.0020 * * * \\
(0.0005)\end{array}$ & $\begin{array}{c}-0.0011 * * * \\
(0.0002)\end{array}$ & $\begin{array}{c}0.0000 \\
(0.0005)\end{array}$ \\
\hline Distance & $\begin{array}{c}-0.0097 * * * \\
(0.0019)\end{array}$ & $\begin{array}{c}-0.0097 * * * \\
(0.0020)\end{array}$ & $\begin{array}{c}-0.0098 * * * \\
(0.0024)\end{array}$ & $\begin{array}{c}-0.0196 * * * \\
(0.0034)\end{array}$ & $\begin{array}{c}-0.0206 * * * \\
(0.0035)\end{array}$ & $\begin{array}{c}-0.0173 * * * \\
(0.0042)\end{array}$ \\
\hline Corruption & $\begin{array}{c}-0.0028 \\
(0.0026)\end{array}$ & $\begin{array}{l}-0.0027 \\
(0.0026)\end{array}$ & & $\begin{array}{c}-0.0135 * * * \\
(0.0042)\end{array}$ & $\begin{array}{c}-0.0128 * * * \\
(0.0041)\end{array}$ & \\
\hline Env Regime & $\begin{array}{c}0.0007 \\
(0.0021)\end{array}$ & & $\begin{array}{c}0.0036 \\
(0.0025)\end{array}$ & $\begin{array}{c}-\mathbf{0 . 0 0 8 5} * * \\
(0.0039)\end{array}$ & & $\begin{array}{l}0.0063 * \\
(0.0036)\end{array}$ \\
\hline $\begin{array}{l}\text { Env Regime } \\
\text { * Emission Index }\end{array}$ & $\begin{array}{c}-0.0026 * * \\
(0.0012)\end{array}$ & $\begin{array}{c}-0.0024 * * \\
(0.0009)\end{array}$ & $\begin{array}{c}-0.0025 * * \\
(0.0012)\end{array}$ & $\begin{array}{c}-0.0029 * * \\
(0.0013)\end{array}$ & $\begin{array}{c}-0.0040 * * * \\
(0.0012)\end{array}$ & $\begin{array}{c}-0.0025 * * * \\
(0.0011)\end{array}$ \\
\hline Number of obs & 6,384 & 6,384 & 7,728 & 3,024 & 3,024 & 4,368 \\
\hline Wald Chi ${ }^{2}$ & 1,330 & 1,305 & 921 & 605 & 1,359 & 1,563 \\
\hline Prob $>\mathrm{Chi}^{2}$ & 0.00 & 0.00 & 0.00 & 0.00 & 0.00 & 0.00 \\
\hline Pseudo $\mathbf{R}^{2}$ & 0.28 & 0.28 & 0.26 & 0.27 & 0.26 & 0.24 \\
\hline
\end{tabular}


Table 5. Alternative measures of environmental standards in host countries

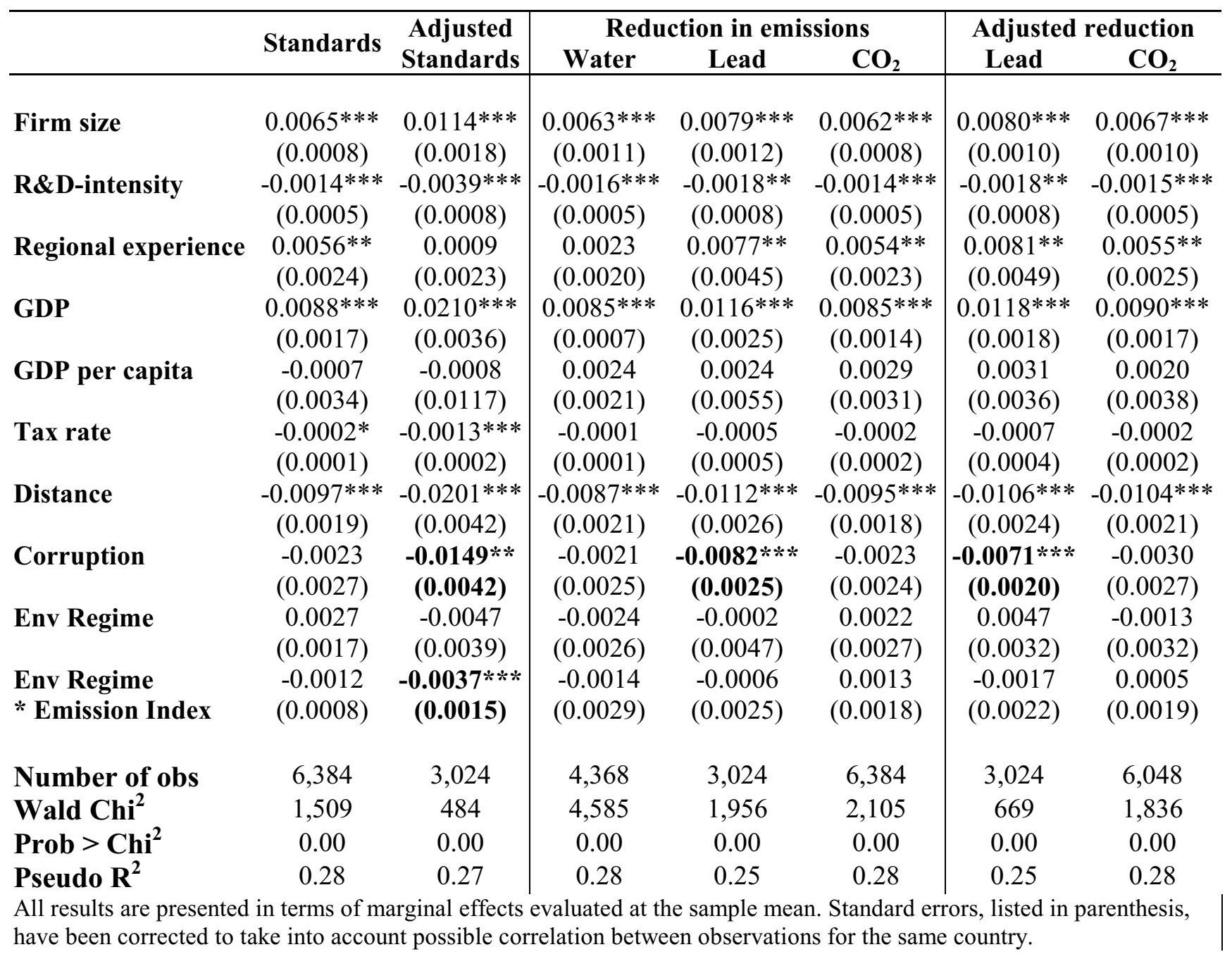


Table 6. Alternative measures of pollution intensity - Abatement costs

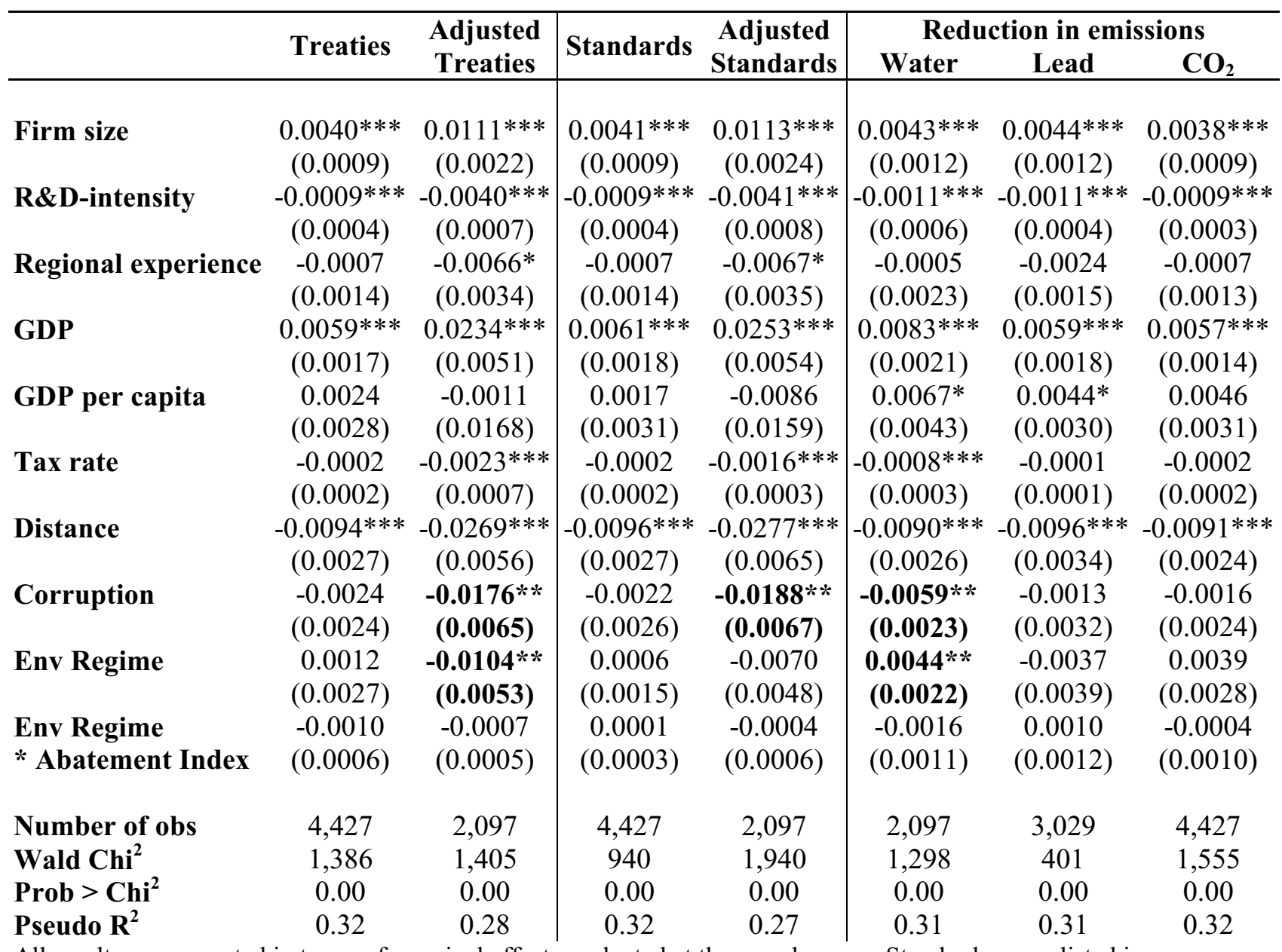

All results are presented in terms of marginal effects evaluated at the sample mean. Standard errors, listed in parenthesis, have been corrected to take into account possible correlation between observations for the same country. 
Table 7. The Subsample of U.S. firms

\begin{tabular}{|c|c|c|c|c|c|c|c|}
\hline & \multirow[b]{2}{*}{ Treaties } & \multirow{2}{*}{$\begin{array}{c}\text { Adjusted } \\
\text { Treaties }\end{array}$} & \multirow[b]{2}{*}{ Standards } & \multirow{2}{*}{$\begin{array}{c}\text { Adjusted } \\
\text { Standards } \\
\end{array}$} & \multicolumn{3}{|c|}{ Reduction in emissions } \\
\hline & & & & & Water & Lead & $\mathrm{CO}_{2}$ \\
\hline Firm size & $\begin{array}{c}0.0041 * * * \\
(0.0013)\end{array}$ & $\begin{array}{c}0.0020 * * * \\
(0.0014)\end{array}$ & $\begin{array}{c}0.0041 * * * \\
(0.0012)\end{array}$ & $\begin{array}{c}0.0021 * * * \\
(0.0015)\end{array}$ & $\begin{array}{c}0.0034 * * * \\
(0.0011)\end{array}$ & $\begin{array}{c}0.0029 * * * \\
(0.0015)\end{array}$ & $\begin{array}{c}0.0038 * * * \\
(0.0012)\end{array}$ \\
\hline R\&D-intensity & $\begin{array}{l}-0.0009^{*} \\
(0.0005)\end{array}$ & $\begin{array}{c}-0.0011 * * * \\
(0.0009)\end{array}$ & $\begin{array}{c}-0.0010^{*} \\
(0.0005)\end{array}$ & $\begin{array}{c}-0.0011^{* * *} \\
(0.0010)\end{array}$ & $\begin{array}{c}-0.0004 \\
(0.0005)\end{array}$ & $\begin{array}{l}-0.0010 \\
(0.0006)\end{array}$ & $\begin{array}{c}-0.0009^{*} \\
(0.0005)\end{array}$ \\
\hline Regional experience & $\begin{array}{c}0.0182 * * * \\
(0.0066)\end{array}$ & $\begin{array}{c}0.0070^{* * *} \\
(0.0055)\end{array}$ & $\begin{array}{c}0.0183 * * * \\
(0.0064)\end{array}$ & $\begin{array}{c}0.0070^{* * *} \\
(0.0056)\end{array}$ & $\begin{array}{c}0.0152 * * * \\
(0.0067)\end{array}$ & $\begin{array}{c}0.0120 * * * \\
(0.0077)\end{array}$ & $\begin{array}{c}0.0174 * * * \\
(0.0060)\end{array}$ \\
\hline GDP & $\begin{array}{r}0.0050^{*} \\
(0.002\end{array}$ & $\begin{array}{c}0.0027 * * * \\
(0.0024)\end{array}$ & $\begin{array}{c}0.0051 * * * \\
(0.0021)\end{array}$ & $\begin{array}{c}0.0027 * * * \\
(0.0025)\end{array}$ & $\begin{array}{c}0.0011^{* *} \\
(0.0007)\end{array}$ & $\begin{array}{c}0.0034 * * * \\
(0.0018)\end{array}$ & $\begin{array}{c}0.0048 * * * \\
(0.0020)\end{array}$ \\
\hline GDP per capita & $\begin{array}{l}-0.0030^{*} \\
(0.0020)\end{array}$ & $\begin{array}{l}-0.0024 \\
(0.0034)\end{array}$ & $\begin{array}{c}-0.0040^{* *} \\
(0.0022)\end{array}$ & $\begin{array}{l}-0.0016 \\
(0.0030)\end{array}$ & $\begin{array}{c}-0.0075 * * * \\
(0.0020)\end{array}$ & $\begin{array}{l}-0.0017^{*} \\
(0.0009)\end{array}$ & $\begin{array}{l}-0.0028 \\
(0.0021)\end{array}$ \\
\hline Tax rate & $\begin{array}{l}-0.0001 \\
(0.0001)\end{array}$ & $\begin{array}{c}0.0000 \\
(0.0001)\end{array}$ & $\begin{array}{c}0.0000 \\
(0.0001)\end{array}$ & $\begin{array}{c}0.0000 \\
(0.0001)\end{array}$ & $\begin{array}{c}0.0004 * * * \\
(0.0001)\end{array}$ & $\begin{array}{c}0.0000 \\
(0.0001)\end{array}$ & $\begin{array}{c}0.0000 \\
(0.0001)\end{array}$ \\
\hline Distance & $\begin{array}{c}-0.0312 * * * \\
(0.0129)\end{array}$ & $\begin{array}{c}-0.0318 * * * \\
(0.0269)\end{array}$ & $\begin{array}{c}-0.0276 * * * \\
(0.0126)\end{array}$ & $\begin{array}{c}-0.0303 * * * \\
(0.0258)\end{array}$ & $\begin{array}{c}-0.0705 * * * \\
(0.0202)\end{array}$ & $\begin{array}{c}-0.0040 \\
(0.0102)\end{array}$ & $\begin{array}{c}-0.0260 * * * \\
(0.0116)\end{array}$ \\
\hline Corruption & $\begin{array}{c}0.0002 \\
(0.0013)\end{array}$ & $\begin{array}{l}-0.0002 \\
(0.0008)\end{array}$ & $\begin{array}{c}0.0001 \\
(0.0012)\end{array}$ & $\begin{array}{l}-0.0005 \\
(0.0010)\end{array}$ & $\begin{array}{c}0.0014 * * * \\
(0.0006)\end{array}$ & $\begin{array}{l}-0.0013 * \\
(0.0009)\end{array}$ & $\begin{array}{l}-0.0002 \\
(0.0011)\end{array}$ \\
\hline Env Regime & $\begin{array}{c}-0.0017 \\
(0.0013)\end{array}$ & $\begin{array}{c}-0.0002 \\
(0.0007)\end{array}$ & $\begin{array}{c}-0.0003 \\
(0.0012)\end{array}$ & $\begin{array}{c}-0.0008 \\
(0.0008)\end{array}$ & $\begin{array}{c}-0.0045 * * * \\
(0.0010)\end{array}$ & $\begin{array}{c}-0.0016 * * \\
(0.0009)\end{array}$ & $\begin{array}{l}0.0034 * \\
(0.0022)\end{array}$ \\
\hline $\begin{array}{l}\text { Env Regime } \\
\text { * Emission Index }\end{array}$ & $\begin{array}{c}0.0008 \\
(0.0011)\end{array}$ & $\begin{array}{l}0.0006 * * \\
(0.0005)\end{array}$ & $\begin{array}{c}0.0010 \\
(0.0010)\end{array}$ & $\begin{array}{c}0.0005 \\
(0.0004)\end{array}$ & $\begin{array}{c}-0.0013 \\
(0.0018)\end{array}$ & $\begin{array}{c}0.0010 \\
(0.0007)\end{array}$ & $\begin{array}{l}-0.0029 \\
(0.0022)\end{array}$ \\
\hline & 1,368 & & 1,368 & & 648 & 936 & 1,368 \\
\hline Wald Chi ${ }^{2}$ & 235 & & 363 & 846 & 222 & 766 & 198 \\
\hline Prob $>\mathrm{Chi}^{2}$ & & & 0.00 & 0.00 & 0.00 & 0.00 & 0.00 \\
\hline Pseudo $\mathbf{R}^{2}$ & 0.35 & 0.42 & 0.36 & 0.42 & 0.39 & 0.39 & 0.36 \\
\hline
\end{tabular}

All results are presented in terms of marginal effects evaluated at the sample mean. Standard errors, listed in parenthesis, have been corrected to take into account possible correlation between observations for the same country. 
Table 8a. Alternative Measure of Corruption - Neumann index

\begin{tabular}{|c|c|c|c|c|c|c|c|}
\hline & \multirow[b]{2}{*}{ Treaties } & \multirow{2}{*}{$\begin{array}{c}\text { Adjusted } \\
\text { Treaties }\end{array}$} & \multirow[b]{2}{*}{ Standards } & \multirow{2}{*}{$\begin{array}{l}\text { Adjusted } \\
\text { Standards }\end{array}$} & \multicolumn{3}{|c|}{ Reduction in emissions } \\
\hline & & & & & Water & Lead & $\mathrm{CO}_{2}$ \\
\hline Firm size & $\begin{array}{c}0.0070 * * * \\
(0.0010)\end{array}$ & $\begin{array}{c}0.0107 * * * \\
(0.0017)\end{array}$ & $\begin{array}{c}0.0073 * * * \\
(0.0009)\end{array}$ & $\begin{array}{c}0.0107 * * * \\
(0.0016)\end{array}$ & $\begin{array}{c}0.0078 * * * \\
(0.0014)\end{array}$ & $\begin{array}{c}0.0071 * * * \\
(0.0013)\end{array}$ & $\begin{array}{c}0.0068^{* * *} * \\
(0.0010)\end{array}$ \\
\hline R\&D-intensity & $\begin{array}{c}-0.0015 * * * \\
(0.0005)\end{array}$ & $\begin{array}{c}-0.0032 * * * \\
(0.0009)\end{array}$ & $\begin{array}{c}-0.0015^{* * *} * \\
(0.0005)\end{array}$ & $\begin{array}{c}-0.0032 * * * \\
(0.0008)\end{array}$ & $\begin{array}{c}-0.0016^{* *} \\
(0.0009)\end{array}$ & $\begin{array}{c}-0.0016^{* * *} \\
(0.0006)\end{array}$ & $\begin{array}{c}-0.0014 * * * \\
(0.0005)\end{array}$ \\
\hline Regional experience & $\begin{array}{c}0.0065 * * \\
(0.0027)\end{array}$ & $\begin{array}{c}0.0034 \\
(0.0036)\end{array}$ & $\begin{array}{c}0.0071 * * \\
(0.0029)\end{array}$ & $\begin{array}{c}0.0035 \\
(0.0036)\end{array}$ & $\begin{array}{c}0.0087 * * \\
(0.0040)\end{array}$ & $\begin{array}{c}0.0038 \\
(0.0027)\end{array}$ & $\begin{array}{c}0.0063 * * \\
(0.0025)\end{array}$ \\
\hline GDP & $\begin{array}{c}0.0097 * * * \\
(0.0023)\end{array}$ & $\begin{array}{c}0.0194 * * * \\
(0.0038)\end{array}$ & $\begin{array}{c}0.0110^{* * * *} \\
(0.0020)\end{array}$ & $\begin{array}{c}0.0194 * * * \\
(0.0038)\end{array}$ & $\begin{array}{c}0.0135 * * * \\
(0.0023)\end{array}$ & $\begin{array}{c}0.0125 * * * \\
(0.0015)\end{array}$ & $\begin{array}{c}0.0104 * * * \\
(0.0014)\end{array}$ \\
\hline GDP per capita & $\begin{array}{c}-0.0013 \\
(0.0025)\end{array}$ & $\begin{array}{c}-0.0183 * * * \\
(0.0074)\end{array}$ & $\begin{array}{c}-0.0058^{*} \\
(0.0033)\end{array}$ & $\begin{array}{c}-0.0240 * * * \\
(0.0075)\end{array}$ & $\begin{array}{c}0.0045 \\
(0.0053)\end{array}$ & $\begin{array}{c}0.0005 \\
(0.0022)\end{array}$ & $\begin{array}{c}0.0044^{*} \\
(0.0023)\end{array}$ \\
\hline Tax rate & $\begin{array}{l}-0.0001 \\
(0.0003)\end{array}$ & $\begin{array}{c}0.0000 \\
(0.0006)\end{array}$ & $\begin{array}{c}-0.0004 \\
(0.0002)\end{array}$ & $\begin{array}{c}-0.0001 \\
(0.0004)\end{array}$ & $\begin{array}{l}-0.0001 \\
(0.0007)\end{array}$ & $\begin{array}{l}-0.0001 \\
(0.0002)\end{array}$ & $\begin{array}{l}-0.0002 \\
(0.0002)\end{array}$ \\
\hline Distance & $\begin{array}{c}-0.0109 * * * \\
(0.0025)\end{array}$ & $\begin{array}{c}-0.0190 * * * \\
(0.0042)\end{array}$ & $\begin{array}{c}-0.0111 * * * \\
(0.0027)\end{array}$ & $\begin{array}{c}-0.0185^{* * *} * \\
(0.0038)\end{array}$ & $\begin{array}{c}-0.0109 * * * \\
(0.0036)\end{array}$ & $\begin{array}{c}-0.0099 * * * \\
(0.0026)\end{array}$ & $\begin{array}{c}-0.0107 * * * \\
(0.0024)\end{array}$ \\
\hline Corruption & $\begin{array}{c}-0.0006 \\
(0.0010)\end{array}$ & $\begin{array}{l}-0.0028 \\
(0.0019)\end{array}$ & $\begin{array}{l}-0.0002 \\
(0.0011)\end{array}$ & $\begin{array}{c}-0.0031 \\
(0.0020)\end{array}$ & $\begin{array}{l}-0.0044^{*} \\
(0.0024)\end{array}$ & $\begin{array}{c}-0.0005 \\
(0.0011)\end{array}$ & $\begin{array}{c}-0.0002 \\
(0.0010)\end{array}$ \\
\hline Env Standards & $\begin{array}{c}0.0059 \\
(0.0046)\end{array}$ & $\begin{array}{c}0.0097 * * \\
(0.0039)\end{array}$ & $\begin{array}{c}0.0067 * * * * \\
(0.0020)\end{array}$ & $\begin{array}{c}0.0135 * * * \\
(0.0031)\end{array}$ & $\begin{array}{c}0.0044 \\
(0.0036)\end{array}$ & $\begin{array}{l}-0.0045 * \\
(0.0027)\end{array}$ & $\begin{array}{l}0.0064 * * \\
(0.0026)\end{array}$ \\
\hline $\begin{array}{l}\text { Env Regime } \\
\text { * Emission Index }\end{array}$ & $\begin{array}{c}-0.0025 * \\
(0.0014)\end{array}$ & $\begin{array}{c}-0.0029 * * * \\
(0.0012)\end{array}$ & $\begin{array}{c}-0.0016 * \\
(0.0009)\end{array}$ & $\begin{array}{c}-0.0035 * * * \\
(0.0013)\end{array}$ & $\begin{array}{l}-0.0001 \\
(0.0024)\end{array}$ & $\begin{array}{l}-0.0036 \\
(0.0029)\end{array}$ & $\begin{array}{c}0.0021 \\
(0.0014)\end{array}$ \\
\hline Number of obs & & 4,032 & & & 3,360 & 5,040 & 7,056 \\
\hline Wald $\mathrm{Chi}^{2}$ & 2,091 & 983 & 1,404 & 1,146 & 1,246 & 561 & 1,038 \\
\hline Prob $>\mathrm{Chi}^{2}$ & 0.00 & 0.00 & 0.00 & 0.00 & 0.00 & 0.00 & 0.00 \\
\hline Pseudo $\mathbf{R}^{2}$ & 0.25 & 0.23 & 0.25 & 0.23 & 0.23 & 0.24 & 0.25 \\
\hline
\end{tabular}

All results are presented in terms of marginal effects evaluated at the sample mean. Standard errors, listed in parenthesis, have been corrected to take into account possible correlation between observations for the same country. 
Table 8b. Neumann Corruption index with

Pollution Intensity Measured by Abatement Costs

\begin{tabular}{|c|c|c|c|c|c|c|c|}
\hline & \multirow[b]{2}{*}{ Treaties } & \multirow{2}{*}{$\begin{array}{c}\text { Adjusted } \\
\text { Treaties }\end{array}$} & \multirow[b]{2}{*}{ Standards } & \multirow{2}{*}{$\begin{array}{c}\text { Adjusted } \\
\text { Standards } \\
\end{array}$} & \multicolumn{3}{|c|}{ Reduction in emissions } \\
\hline & & & & & Water & Lead & $\mathrm{CO}_{2}$ \\
\hline Firm size & $\begin{array}{c}0.0039 * * * \\
(0.0010)\end{array}$ & $\begin{array}{c}0.0091 * * * \\
(0.0023)\end{array}$ & $\begin{array}{c}0.0050 * * * \\
(0.0011)\end{array}$ & $\begin{array}{c}0.0091 * * * \\
(0.0021)\end{array}$ & $\begin{array}{c}0.0036 * * * \\
(0.0018)\end{array}$ & $\begin{array}{c}0.0050 * * * \\
(0.0014)\end{array}$ & $\begin{array}{c}0.0041 * * * \\
(0.0010)\end{array}$ \\
\hline R\&D-intensity & $\begin{array}{c}-0.0008 * * * \\
(0.0004)\end{array}$ & $\begin{array}{c}-0.0030 * * * \\
(0.0009)\end{array}$ & $\begin{array}{c}-0.0011 * * * \\
(0.0004)\end{array}$ & $\begin{array}{c}-0.0030 * * * \\
(0.0008)\end{array}$ & $\begin{array}{c}-0.0010 * * * \\
(0.0006)\end{array}$ & $\begin{array}{c}-0.0011 * * * \\
(0.0005)\end{array}$ & $\begin{array}{c}-0.0009 * * * \\
(0.0004)\end{array}$ \\
\hline Regional experience & $\begin{array}{l}-0.0005 \\
(0.0016)\end{array}$ & $\begin{array}{l}-0.0040 \\
(0.0042)\end{array}$ & $\begin{array}{l}-0.0004 \\
(0.0021)\end{array}$ & $\begin{array}{l}-0.0039 \\
(0.0042)\end{array}$ & $\begin{array}{c}0.0001 \\
(0.0021)\end{array}$ & $\begin{array}{l}-0.0023 \\
(0.0024)\end{array}$ & $\begin{array}{l}-0.0005 \\
(0.0017)\end{array}$ \\
\hline GDP & $\begin{array}{c}0.0060^{* * * *} \\
(0.0022)\end{array}$ & $\begin{array}{c}0.0204 * * * \\
(0.0051)\end{array}$ & $\begin{array}{c}0.0091 * * * \\
(0.0025)\end{array}$ & $\begin{array}{c}0.0204 * * * \\
(0.0051)\end{array}$ & $\begin{array}{c}0.0100 * * * \\
(0.0019)\end{array}$ & $\begin{array}{c}0.0113 * * * \\
(0.0022)\end{array}$ & $\begin{array}{c}0.0079 * * * \\
(0.0015)\end{array}$ \\
\hline GDP per capita & $\begin{array}{c}0.0001 \\
(0.0020)\end{array}$ & $\begin{array}{r}-0.021 \\
(0.00\end{array}$ & $\begin{array}{l}-0.0042 \\
(0.0037)\end{array}$ & $\begin{array}{r}-0.028 \\
(0.00\end{array}$ & $\begin{array}{c}0.0099 \\
(0.0037)\end{array}$ & $\begin{array}{c}0.0020 \\
(0.0028)\end{array}$ & $\begin{array}{c}0.0060 * * * \\
(0.0021)\end{array}$ \\
\hline Tax rate & $\begin{array}{c}0.0000 \\
(0.0003)\end{array}$ & $\begin{array}{l}-0.0002 \\
(0.0008)\end{array}$ & $\begin{array}{l}-0.0004 \\
(0.0003)\end{array}$ & $\begin{array}{l}-0.0002 \\
(0.0005)\end{array}$ & $\begin{array}{l}-0.0005 \\
(0.0004)\end{array}$ & $\begin{array}{l}-0.0002 \\
(0.0003)\end{array}$ & $\begin{array}{l}-0.0002 \\
(0.0002)\end{array}$ \\
\hline Distance & $\begin{array}{c}-0.0100 * * * \\
(0.0030)\end{array}$ & $\begin{array}{c}-0.0241 * * * \\
(0.0061)\end{array}$ & $\begin{array}{c}-0.0124 * * * \\
(0.0034)\end{array}$ & $\begin{array}{c}-0.0233 * * * \\
(0.0055)\end{array}$ & $\begin{array}{c}-0.0077 * * * \\
(0.0041)\end{array}$ & $\begin{array}{c}-0.0118 * * * \\
(0.0039)\end{array}$ & $\begin{array}{c}-0.0104 * * * \\
(0.0030)\end{array}$ \\
\hline Corruption & $\begin{array}{l}-0.0009 \\
(0.0009)\end{array}$ & & $\begin{array}{l}-0.0006 \\
(0.0013)\end{array}$ & $\begin{array}{l}-0.0044^{*} \\
(0.0024)\end{array}$ & $\begin{array}{c}-0.0037^{* *} \\
(0.0013)\end{array}$ & $\begin{array}{l}-0.0 \\
(0.0\end{array}$ & $\begin{array}{l}-0.0006 \\
(0.0009)\end{array}$ \\
\hline Env Standards & $\begin{array}{c}0.0072 \\
(0.0045)\end{array}$ & $\begin{array}{l}0.0085 * \\
(0.0047)\end{array}$ & $\begin{array}{l}0.0048 * * \\
(0.0022)\end{array}$ & $\begin{array}{c}0.0121 * * * \\
(0.0033)\end{array}$ & $\begin{array}{c}0.0111 \\
(0.0030)\end{array}$ & $\begin{array}{c}-0.0105 * * * \\
(0.0044)\end{array}$ & $\begin{array}{c}0.0089 * * * \\
(0.0035)\end{array}$ \\
\hline $\begin{array}{l}\text { Env Regime } \\
\text { * Abatement Index }\end{array}$ & $\begin{array}{l}-0.0012 \% \\
(0.0007)\end{array}$ & $\begin{array}{c}0.0001 \\
(0.0010)\end{array}$ & $\begin{array}{l}-0.0001 \\
(0.0005)\end{array}$ & $\begin{array}{c}0.0003 \\
(0.0010)\end{array}$ & $\begin{array}{l}-0.0017 \\
(0.0016)\end{array}$ & $\begin{array}{c}0.0003 \\
(0.0010)\end{array}$ & $\begin{array}{c}0.0002 \\
(0.0008)\end{array}$ \\
\hline Number of o & & & & & 2,330 & & 4,893 \\
\hline Wald $\mathrm{Chi}^{2}$ & 866 & & & & 415 & 735 & 398 \\
\hline Prob $>\mathrm{Chi}^{2}$ & & & 0.00 & 0.00 & 0.00 & 0.00 & 0.00 \\
\hline Pseudo $\mathbf{R}^{2}$ & 0.28 & 0.24 & 0.28 & 0.25 & 0.30 & 0.27 & 0.29 \\
\hline
\end{tabular}

All results are presented in terms of marginal effects evaluated at the sample mean. Standard errors, listed in parenthesis, have been corrected to take into account possible correlation between observations for the same country. 